практ. конф. - Саратов, 2017. - С 14-17.

13. Уша Б.В. Клиническая диагностика внутренних незаразных болезней. - СПб.: Квадро, 2013. - 490 с.

14. Физиология сельскохозяйственных животных / В.Г. Гусаков [и др.]. -Витебск, 2008. - 274 с.

15. Reference Value Advisor: a new freeware set of macroinstructions to calculate reference intervals with Microsoft Excel / A. Geffre [et al.] // Vet. Clin. Pathol., 2011, Vol. 40, No. 1, P. 107-112.

Алехин Юрий Николаевич, $\partial-p$ вет. наук, главный научный сотрудник, Всероссийский научно-исследовательский институт патологии, фармакологии и терапии Российской академии сельскохозяйственных наук. Россия.

Жуков Максим Сергеевич, канд. вет. наук, младший научный сотрудник, Всероссийский научно-исследовательский институт патологии, фармакологии и терапии Российской академии сельскохозяйственных наук. Россия.

394087, г. Воронеж, ул. Ломоносова, 114-Б.

Тел.: (473) 253-62-10.

Калюжный Иван Исаевич, $\partial-p$ вет. наук, проф. кафедры «Болезни животных и ветеринарно-санитарная экспертиза», Саратовский государственный аграрный университет имени Н.И. Вавилова.

410012, г. Саратов, Театральнаяпл., 1.

Тел.: (8452) 69-24-25.

Ключевые слова: крупный рогатый скот; рубцовое пищеварение; метод диагностики; эндогенная интоксикация; ацицоз; алкалоз.

\title{
UNIFICATION OF THE METHOD FOR DETERMINING THE AVERAGE MASS MOLECULES FOR THE DIAGNOSIS OF DISORDERS OF CICATRI-CAL DIGESTION IN RUMINANTS
}

Alekhin Yurij Nikolaevich, Doctor of Veterinary Sciences, State Scientific Institu-tion All-Russian Veterinary Research Institute of Pathology, Pharmacology and Therapy of the Russian Academy of Agricultural Sciences. Russia.

Zhukov Maksim Sergeevich, Junior Researcher, State Scientific Institution All-Russian Veterinary Research Institute of Pathology, Pharmacology and Therapy of the Russian Academy of Agricultural Sciences. Russia.

Kalyuzniy Ivan Isaevich, Doctor of Veterinary Sciences, Professor of the chair "Diseases of Animals and Veterinarian-sanitarian Expertise", Saratov State Agrar-ian University named after N.I. Vavilov. Russia.
Keywords: cattle; cicatricial digestion; method of diagnosis; endogenous intoxica-tion; acidosis; alkalosis.

Abstract. The carried out researches have shown that the developed way of diag-nostics of disorders of cicatrical digestion in ruminants allows to reveal a pathol-ogy at early stages of development, and in patients - to estimate the degree of vio-lation of cicatricial digestion and the effectiveness of the treatment. The clinically healthy state of animals is indicated by the level of the content of the average molecules (CAM) in the scar liquid, determined at a wavelength of $237 \mathrm{~nm}$ - less than 2.0 conventional units, at a wave of $254 \mathrm{~nm}$ - less than 1.0 conventional units, at a wavelength of $280 \mathrm{~nm}$ - less than 1.0 conventional units.

удк 619612.1.636.2

\section{ВЛИЯНИЕ НЕОРГАНИЧЕСКИХ И ОРГАНИЧЕСКИХ ФОРМ МИКРОЭЛЕМЕНТОВ НА МЕТАБОЛИЧЕСКИЕ ПРОЦЕССЫ В ОРГАНИЗМЕ ДОЙНЫХ КОРОВ}

\author{
БЫКОВА Елена Владимировна, Саратовский государственный аграрный университет имени \\ Н.И. Вавилова
}

КОРОБОВ Александр Петрович, Саратовский государственный аграрный университет имени Н.И. Вавилова

КАЛЮЖНЫЙ Иван Исаевич, Саратовский государственный аграрный университет имени Н.И. Вавилова

ГУМЕНЮК Анатолий Петрович, $A O$ «Биоамид»

Изучено влияние неорганическх и органических форм микроэлементов на метаболические процессы в организме дойных коров. Установлено, что различные формы микроэлементов действуют на обменные процессы в организме животных. Лучшие показатели, в пределах физиологических норм, морфологического и биохимического состава крови были у животных, получавших в составе премиксов органические соединения марганца, иинка, меди, кобальта, селена и йода. Введение в состав рационов коров органических форм микроэлементов улучшает молочную продуктивность и качественные показатели молока.

Введение. Недостаток минеральных веществ в рационах животных традиционно принято компенсировать введением их в корма в неорганической форме в виде сульфатов, карбонатов, хлоридов и др. В последние годы во всем мире проявляется интерес к использованию органических соединений микроэлементов [7]. Российской компанией АO «Биоамид» разработан новый органический продукт - «Органические микроэлементные комплексы на основе органических соединений («ОМЭК-7МЭ»)».
Особенность «ОМЭК-7МЭ» состоит в том, что он представляет собой готовую смесь необходимых микроэлементов в форме органических соединений с оптимальным соотношением составных частей для любого вида животных. Микроэлементная часть, включающая металлы (железо, медь, цинк, марганец, кобальт), представляет собой комплексные соединения их c L-аспарагиновой кислотой. Смесь соединений металлов с L-аспарагиновой кислотой получают из единого технологического раствора и любые высушенные частицы смеси аб- 
солютно идентичны по составу. Такого идеального распределения невозможно достичь при механическом смешивании отдельных соединений [3].

Селен в смеси представлен в виде запатентованного соединения с органическим соединением ароматического ряда «ДАФС-25». Йод в смеси представлен ковалентным соединением с белковой частью биомассы хлебопекарных дрожжей. В таком виде он устойчив к воздействию внешних факторов и не теряется в процессе производства корма и при хранении, что свойственно неорганическим соединениям йода.

Целью настоящей работы является обоснование минерального питания высокопродуктивного молочного скота в условиях Левобережья Саратовской области.

Методика исследований. В ходе исследований определяли влияние неорганических и органических форм микроэлементов в составе премиксов на морфологические и биохимические показатели крови коров, состояние рубцового пищеварения, молочную продуктивность и состав молока. Сравнительное изучение влияния неорганических и органических микроминеральных подкормок в виде аспарагинатов (АО «Биоамид») на метаболические процессы в организме дойных коров и молочную продуктивность проводили на молочной ферме КФХ Быковой О.М. в летний пастбищный период 2016 г.

Для проведения опыта по принципу аналогов были сформированы три группы коров по 8 голов в каждой живой массой 500-550 кг. Животных подбирали с учетом породы, возраста, лактации, даты последнего отела, уровня продуктивности (по 2-3 лактации со среднесуточным уровнем продуктивности 18-20 л). Схема научно-хозяйственного опыта приведена в табл. 1.

Нормы кормления дойных коров с живой массой 500 кг и удоем 20 кг в сутки [6] предусматривают получение животными 17,0 ЭКЕ, 170 МДж обменной энергии 17,3 кг сухого вещества 2320 г сырого протеина, 4150 г сырой клетчатки, 1400 г сахара, 12,6 мг йода. Основной рацион был полноценным по уровню энергии, основным группам питательных веществ, но дефицитным по некоторым макро- и микроэлементам. В частности, недостаток йода составил 10,4 мг на 1 голову. Содержание йода в основном рационе составило 0,13 мг на 1 кг сухого вещества.

Животные контрольной группы в учетный период опыта получали в составе специального премикса по 2 мг ОМЭК-Ј, что в пересчете на 1 кг су- хого вещества составило 0,11 мг, общее количество йода - 0,24 мг/кг, по нашему мнению, оказалось недостаточным для нормализации обменных процессов в организме.

Животные 1-й опытной группы в дополнение к основному рациону в составе премикса получали по 10 мг йода в виде йодистого калия, или 0,58 мг йода на 1 кг сухого вещества. Животные 2-й опытной группы получали йод в неорганической и органической формах. Общее количество йода составило 0,81 мг на 1 кг сухого вещества.

Результаты исследований. В ходе опыта изучали такие показатели, как морфологический и биохимический состав крови, валовый удой, содержание жира и белка в молоке. Исследования крови в начале и конце опыта проводили в химической лаборатории ветеринарного госпиталя СГАУ им. Н.И. Вавилова. Морфологический и биохимический состав крови является показателем физиологического состояния организма и предопределяет продуктивные, адаптационные и воспроизводительные способности животных $[1,2]$. Морфологический состав и биохимические анализы крови подопытных коров в начале и конце опыта приводятся в табл. $2,3$.

Показатели морфологического состава крови находились в пределах физиологической нормы. Наряду с этим у всех животных отмечали повышение количества эритроцитов, в контрольной и 1-й опытной группах - увеличение содержания лейкоцитов, у животных, получавших йодистый калий и йод в виде ОМЭК-Ј, - увеличение числа тромбоцитов. Во всех подопытных группах уменьшалось содержание гранулоцитов, повышалось содержание лимфоцитов, моноцитов, кроме 2-й опытной группы. Незначительные изменения отмечали в содержании гемоглобина, цветном показателе, ширине распределения эритроцитов, среднем объеме эритроцитов, средней концентрации гемоглобина в эритроцитах, среднем объеме тромбоцита, ширине распределения тромбоцитов, которая несколько увеличилась в 1-й опытной группе. Наблюдали увеличение тромбокрита во 2-й опытной группе. В группе, получавшей неорганический и органический йод, незначительно уменьшались гемоглобин и гематокрит. Исходя из этого, можно предположить активизацию гемопоэза у животных 1-й и 2-й опытных групп по сравнению с контрольной.

Установлено, что содержание общего белка в крови коров, получавших органический йод в конце опыта, уменьшилось на $11,2 \%$, у получавших сульфаты микроэлементов - на 5,2 \%, у получав-

Таблица 1

\section{Схема опыта}

\begin{tabular}{|c|c|c|}
\hline Группа & Предварительный период, 31 день & Учетный период, 92 дня \\
\hline Контрольная & $\begin{array}{c}\text { ОР } \\
\text { (основной рацион) }\end{array}$ & $\begin{array}{c}\text { ОР+ОМЭК+ 20 г йода в виде ОМЭК-J } \\
\text { на 1 т премикса }\end{array}$ \\
\hline 1-я опытная & ОР & $\begin{array}{c}\text { ОР+сульфаты микроэлементов, 100 г } \\
\text { йода в виде КІ на 1 т премикса }\end{array}$ \\
\hline 2-я опытная & ОР & $\begin{array}{c}\text { ОР+ОМЭК + 100 г йода в виде КІ+20 г } \\
\text { йода в виде ОМЭК-Ј на 1 т премикса }\end{array}$ \\
\hline
\end{tabular}


Морфологический состав крови подопытных коров

\begin{tabular}{|l|c|c|c|c|c|c|}
\hline \multirow{2}{*}{\multicolumn{1}{|c|}{ Показатель }} & \multicolumn{6}{|c|}{ Группа } \\
\cline { 2 - 7 } & \multicolumn{2}{|c|}{ контрольная } & \multicolumn{2}{c|}{ 1-я опытная } & \multicolumn{2}{c|}{ 2-я опытная } \\
\cline { 2 - 7 } & в начале & в конце & вначале & в конце & в начале & в конце \\
\hline Эритроциты, 1012/л & $5,85 \pm 0,6$ & $8,0 \pm 1,1$ & $5,32 \pm 0,4$ & $5,57 \pm 0,6$ & $5,6 \pm 0,6$ & $6,72 \pm 0,2$ \\
\hline Лейкоциты, 10\%л & $6,7 \pm 1,0$ & $14,5 \pm 2,6$ & $9,5 \pm 2,7$ & $15,3 \pm 1,7$ & $18,7 \pm 4,1$ & $9,3 \pm 1,0$ \\
\hline Тромбоциты, 10\%л & $226 \pm 24$ & $146 \pm 30$ & $247 \pm 69$ & $205 \pm 47$ & $201 \pm 12$ & $259 \pm 50$ \\
\hline Гранулоциты, \% & $81,8 \pm 3,8$ & $62,5 \pm 8,8$ & $80,36 \pm 5,8$ & $62,25 \pm 5,4$ & $74,3 \pm 8,2$ & $68,5 \pm 9,7$ \\
\hline Лимфоциты, \% & $14,6 \pm 3,5$ & $63,6 \pm 26$ & $16,6 \pm 5,1$ & $32,0 \pm 4,4$ & $20,3 \pm 6,5$ & $27,1 \pm 9,0$ \\
\hline Моноциты, \% & $3,5 \pm 0,6$ & $6,2 \pm 1,4$ & $2,9 \pm 0,7$ & $5,7 \pm 1,2$ & $5,4 \pm 1,8$ & $4,2 \pm 0,7$ \\
\hline $\begin{array}{l}\text { Среднее содержание } \\
\text { Нb в эритроцитах, pg }\end{array}$ & $20,6 \pm 3,3$ & $19,5 \pm 2,8$ & $20,5 \pm 3,3$ & $23,1 \pm 0,5$ & $24,7 \pm 2,1$ & $20,0 \pm 2,1$ \\
\hline Цветной показатель & $1,0 \pm 0,2$ & $1,6 \pm 0,2$ & $1,1 \pm 0,3$ & $1,22 \pm 0,2$ & $1,3 \pm 0,2$ & $1,2 \pm 0,2$ \\
\hline $\begin{array}{l}\text { Ширина распределе- } \\
\text { ния эритоцитов }\end{array}$ & $13,0 \pm 1,2$ & $14,9 \pm 1,2$ & $13,1 \pm 1,6$ & $12,2 \pm 0,8$ & $12,4 \pm 0,3$ & $12,1 \pm 0,7$ \\
\hline $\begin{array}{l}\text { Средний объем эрит- } \\
\text { роцитов, фл }\end{array}$ & $60,0 \pm 10,2$ & $46,3 \pm 4,2$ & $58,8 \pm 9,5$ & $65,2 \pm 2,1$ & $68,4 \pm 3,0$ & $50,6 \pm 6,1$ \\
\hline $\begin{array}{l}\text { Средняя концентра- } \\
\text { ция гемоглобина в } \\
\text { эритроцитах RDW, } \\
\text { г/л }\end{array}$ & $345 \pm 7,6$ & $417 \pm 22$ & $351 \pm 5,7$ & $357 \pm 14$ & $361 \pm 14$ & $400 \pm 7,4$ \\
\hline $\begin{array}{l}\text { Средний объем тром- } \\
\text { боцита, фл }\end{array}$ & $7,5 \pm 0,4$ & $7,1 \pm 0,3$ & $7,8 \pm 0,4$ & $8,3 \pm 0,2$ & $8,8 \pm 0,3$ & $7,9 \pm 0,3$ \\
\hline $\begin{array}{l}\text { Ширина распределе- } \\
\text { ния тромбоцитов }\end{array}$ & $15,5 \pm 0,3$ & $15,2 \pm 0,4$ & $15,7 \pm 0,7$ & $16,7 \pm 0,4$ & $16,4 \pm 0,4$ & $15,7 \pm 0,3$ \\
\hline Тромбокрит РСг, \% & $0,171 \pm 0,02$ & $0,105 \pm 0,025$ & $0,188 \pm 0,04$ & $0,165 \pm 0,03$ & $0,171 \pm 0,09$ & $0,209 \pm 0,04$ \\
\hline Гемоглобин, г/л & $122 \pm 26$ & $150 \pm 12$ & $112 \pm 24$ & $129 \pm 12$ & $136 \pm 3,7$ & $134 \pm 13$ \\
\hline Гематокрит & $35,5 \pm 7,8$ & $36,2 \pm 3,4$ & $31,9 \pm 6,9$ & $36,6 \pm 4,5$ & $37,9 \pm 2,3$ & $33,7 \pm 4,0$ \\
\hline
\end{tabular}

ших ОМЭКи микроэлементы- на 27,6 \%.

Установлено, что содержание общего белка в крови коров контрольной группы к концу опыта снизилось с 72,8 до 65,4 г/л, или на $11,2 \%$; в 1-й опытной группе - с 80,0 до 75,8 г/л, или на 5,2 \%, во 2-й опытной группе - с 86,0 до 62,6 г/л, или на $27,2 \%$. Наши данные о содержании общего белка показали, что они не выходили за пределы физиологической нормы. Однако тенденция снижения его содержания в группе, получавшей органические соли микроэлементов, косвенно свидетельствует об улучшении его использования в данном случае.

Об углеводном обмене у коров судили по содержанию глюкозы в сыворотке крови и активности амилазы. Глюкоза является основным источником энергии для организма, на ее долю приходится более 90 \% всех низкомолекулярных углеводов. По нашим данным, наиболее высокий уровень глюкозы был в крови животных, получавших микроэлементы в органической и неорганической формах, у животных контрольной и 1-й опытной групп он был ниже.

В норме активность амилазы в крови коров составляет 41-98 ед./л. Активность амилазы повышается при различных нарушениях процесса пищеварения в организме. В данном случае в конце учетного периода отмечали повышенную активность этого фермента у животных, получавших сульфаты микроэлементов с неорганическим йодом, и у животных, получавших йод в неорганической и органической формах. Однако эти показатели были в пределах физиологических норм.
Щелочная фосфатаза катализирует гидролитическое расщепление монофосфорных эфиров, приводя к увеличению содержания фосфатионов. Повышенное содержание щелочной фосфатазы является одним из признаков нарушения кальций-фосфорного обмена, костных заболеваний. В конце эксперимента мы отмечали незначительное увеличение щелочной фосфатазы в 1-й и 2-й опытных группах, которое было в пределах физиологических норм.

Аспартатаминотрансфераза (АСТ) - клеточный фермент, участвующий в обмене аминокислот. Наиболее резко активность АСТ возрастает при острых гепатитах, хронических заболеваниях (особенно при мастите). Применение неорганических солей микроэлементов в виде сульфатов и органических солей в виде ОМЭК с неорганическим и органическим йодом привело в нашем случае к улучшению этих показателей в 1-й и 2-й опытных группах.

Активность индикаторного фермента печени аланинаминотрансферазы (АЛТ) снизилась во всех группах, но наибольшее снижение с 66,8 до 41,8 ед./л произошло во 2-й опытной группе. Высвобождение АЛТ происходит при нарушениях клеточных мембран гепатитов и повышении их проницаемости. В конце эксперимента самое низкое содержание АЛТ отмечали у животных 1-й и 2-й опытных групп, соответственно 51,0 и 41,8 ед., в контрольной группе оно составило 59,0 ед./л. Исходя из этого, можно предположить незначительное нарушение морфологической структуры гепатитов у животных 1-й и 2-й опытных групп. 
Биохимические анализы крови коров

\begin{tabular}{|l|c|c|c|c|c|c|c|}
\hline \multirow{2}{*}{\multicolumn{1}{|c|}{ Показатель }} & \multirow{2}{*}{ Норма } & \multicolumn{9}{|c|}{ контрольная } & \multicolumn{2}{|c|}{ 1-я опытная } & \multicolumn{2}{c|}{ 2-я опытная } \\
\cline { 3 - 8 } & & в начале & в конце & в начале & в конце & в начале & в конце \\
\hline Белок общий, г/л & $62-82$ & $72,8 \pm 3,5$ & $65,4 \pm 6,9$ & $80,0 \pm 2,2$ & $75,8 \pm 5,3$ & $86,0 \pm 3,8$ & $62,6 \pm 6,5$ \\
\hline Глюкоза, ммоль & $2,3-4,1$ & $3,6 \pm 0,3$ & $3,3 \pm 0,7$ & $3,6 \pm 0,3$ & $3,2 \pm 0,1$ & $3,7 \pm 0,1$ & $4,1 \pm 0,3$ \\
\hline Амилаза, ед./л & $41-98$ & $73,7 \pm 5,6$ & $66,1 \pm 6,0$ & $68,0 \pm 7,1$ & $78,4 \pm 8,5$ & $58,7 \pm 5,0$ & $73,3 \pm 8,1$ \\
\hline $\begin{array}{l}\text { Щелочная фос- } \\
\text { фатаза, ед./л }\end{array}$ & $18-153$ & $80,3 \pm 5,1$ & $48,6 \pm 3,6$ & $63 \pm 16$ & $125 \pm 12$ & $60,6 \pm 8,7$ & $64,9 \pm 5,8$ \\
\hline АСТ, ед./л & $45-110$ & $50,3 \pm 4,6$ & $63,8 \pm 9,8$ & $52,5 \pm 3,3$ & $52,5 \pm 3,3$ & $54,3 \pm 7,8$ & $48,0 \pm 5,6$ \\
\hline АЛТ, ед./л & $6,9-35$ & $66,9 \pm 4,2$ & $59,0 \pm 13$ & $65,6 \pm 1,9$ & $51,0 \pm 10$ & $66,8 \pm 4,4$ & $41,8 \pm 2,6$ \\
\hline $\begin{array}{l}\text { Коэффициент де } \\
\text { Ритиса }\end{array}$ & 1 & 0,75 & 1,07 & 0,8 & 1,31 & 0,81 & 1,15 \\
\hline $\begin{array}{l}\text { Билирубин об- } \\
\text { щий, мкмоль/л }\end{array}$ & $1,7-5,1$ & $11,8 \pm 1,0$ & $11,0 \pm 1,4$ & $10,8 \pm 0,9$ & $10,6 \pm 0,6$ & $12,5 \pm 1,6$ & $9,1 \pm 0,6$ \\
\hline $\begin{array}{l}\text { Лактатдегидро- } \\
\text { геназа, } \\
\text { МЕ/л }\end{array}$ & $240-480$ & $73,0 \pm 3,5$ & $154,0 \pm 69$ & $92,8 \pm 8,6$ & $533,0 \pm 29$ & $80,0 \pm 18$ & $446,0 \pm 58$ \\
\hline Кальций, ммоль/л & $2,1-2,8$ & $2,6 \pm 0,1$ & $2,5 \pm 0,2$ & $2,5 \pm 0,1$ & $2,6 \pm 0,2$ & $2,7 \pm 0,1$ & $2,0 \pm 0,2$ \\
\hline Фосфор, ммоль/л & $1,4-2,5$ & $1,6 \pm 0,1$ & $1,7 \pm 0,1$ & $1,4 \pm 0,1$ & $1,7 \pm 0,1$ & $1,4 \pm 0,1$ & $1,6 \pm 0,2$ \\
\hline $\begin{array}{l}\text { Креатинин, } \\
\text { мкмоль/л }\end{array}$ & $56-162$ & $80,6 \pm 5,2$ & $77,6 \pm 6,4$ & $77,4 \pm 6,5$ & $77,7 \pm 5,6$ & $71,0 \pm 7,7$ & $68,2 \pm 7,0$ \\
\hline $\begin{array}{l}\text { Отношение каль- } \\
\text { ция к фосфору }\end{array}$ & $1: 1,5-2,0$ & $1: 1,63$ & $1: 1,47$ & $1: 1,75$ & $1: 1,55$ & $1: 1,95$ & $1: 1,28$ \\
\hline
\end{tabular}

Коэффициент де Ритиса - соотношение активности трансфераз сыворотки крови, большей частью содержащейся в сердечной мышце (ACT) и печени (АЛТ). В норме коэффициент де Ритиса составляет 1. При повреждении мышечной ткани сердца коэффициент де Ритиса увеличивается, становится больше нормального значения. В нашем случае в конце учетного периода опыта коэффициент де Ритиса в контрольной группе составил 1,08 , в 1-й и 2-й группах соответственно 1,31 и 1,15 ед.

При поражении клеток печени гепатоцитов высвобождается большее количество АЛТ, а активность АСТ изменяется незначительно. При гепатитах различной этиологии коэффициент де Ритиса будет меньше 1 . По результатам наших исследований можно сделать заключение о благоприятном показателе коэффициента де Ритиса у животных подопытных групп, хотя наибольшая разница отмечена у животных 1-й и 2-й опытных групп, что указывает на нормальное функциональное состояние печени и сердца у коров.

Билирубин является конечным продуктом распада гемоглобина. Определение его используется для оценки функции печени. Общий билирубин в конце учетного периода у животных контрольной группы составил 11,0 мкмоль/л, в 1-й и 2-й опытных группах соответственно 10,6 и 9,1 мкмоль/л.

Нормальный уровень активности лактатдегидрогеназы (ЛДГ) составляет 240-480 ME/л. Физиологическое повышение активности ЛДГ наблюдается при заболевании печени, анемии, злокачественных образованиях. В нашем случае в конце учетного периода отмечали повышение активности ЛДГ с 154,0 МЕ/л в контрольной группе до 533,0 и 446,0 ME/л соответственно в 1-й и 2-й опытных группах. Данные изменения являются следствием активизации энергетических процессов в организме животных, в частности углеводного обмена.

Для определения минерального обмена проводили исследования сыворотки крови на содержание кальция, фосфора, устанавливали активность щелочной фосфатазы, тесно связанной с обменом $\mathrm{Ca}^{2}+$ и $\mathrm{P}^{3}+$. Концентрация кальция и фосфора в сыворотке крови коров как контрольной, так и опытных групп находилась в пределах физиологических границ. Отношение кальция к фосфору у всех животных в конце опыта было на уровне 1,3-1,5 при норме 1,0:1,5-2.0

Креатин поступает в организм с кормом и в организме необратимо преобразуется в креатинин. Излишек креатина и креатинина удаляется с мочой. Изменения креатин-креатининового обмена говорит о нарушениях биохимии крови. Возможные причины повышения концентрации креатинина - лейкозы, инфекции. В нашем опыте в конце учетного периода наблюдали уменьшение креатинина в 1-й и 2-й опытных группах.

Лабораторные исследования содержимого рубца проводили на базе кафедры «Терапия, акушерство, фармакология, паразитология и эпизоотология» Саратовского ГАУ им. Н.И. Вавилова и химической лаборатории АО «Биоамид». Величина $\mathrm{pH}$, содержание летучих жирных кислот (уксусной, пропионовой и масляной) в содержимом рубца приводятся в табл.4.

Углеводы корма ферментируются микроорганизмами сложного желудка до 45 \% в ЛЖК, которые всасываются в кровь и на 40-70 \% обеспечивают потребность животных в энергии. Уксусная, пропионовая и масляная кислоты в соотношении 65:20:15 составляют $95 \%$ всех ЛЖК [4]. Их количество и соотношение зависят от состава рациона, 
обмена веществ, содержания структурных элементов. Известно, что соотношение уксусной и пропионовой кислот влияет на содержание жира в молоке [5]. При соотношении уксусной и пропионовой кислот 1:1 жирность молока составляет $1,6-2,0 \%$, при соотношении $2: 1-2,5-3,0 \%$ и при соотношении $3: 1$ - 4,0 \%. Сводные результаты учета молочной продуктивности за период опыта приведены в табл. 5.

Анализ данных табл. 5 показывает, что разные формы микроэлементов оказывают различное влияние на количество и качество полученного молока. В нашем эксперименте лучшие результаты были полученыво 2-й опытной группе, в которой животные получали микроэлементы в органической форме и йод в органической и неорганической формах. Считаем, что введение в состав премикса органического йода в виде ОМЭК-Ј в количестве 20 г/т премикса и 100г КІ на 1 т премикса является перспективным.

Проведение учетного периода эксперимента в течение июня, июля и августа 2016 г. совпало с аномально высокой температурой воздуха. По данным Саратовского справочно-информационного портала «Погода и климат», средние дневные температуры в мае 2016 г. составили $20,8^{\circ} \mathrm{C}$, в июне $25,9^{\circ} \mathrm{C}$, в июле $29,4^{\circ} \mathrm{C}$ и в августе $31,7^{\circ} \mathrm{C}$. Максимальные температуры в конце мая колебались от 25,5 до $29,2^{\circ} \mathrm{C}$. В июне они уже доходили до $30,8-33,0{ }^{\circ} \mathrm{C}$, в июле до $35,2-35,5^{\circ} \mathrm{C}$, в августе до 33,5 до $36,6^{\circ} \mathrm{C}$. Повышение температуры окружающей среды отрицательно влияет на поедание кормов животными, что сказывается на уровне молочной продуктивности. В нашем эксперименте за учетный период произошло снижение молочной продуктивности во всех подопытных группах, но наименьшим оно было в 1-й группе.

Оптимальную продуктивность коров отмечали при комфортной температуре $-5 \ldots+20^{\circ} \mathrm{C}$. При температуре ниже $5{ }^{\circ} \mathrm{C}$ животные используют энергию для поддержания температуры своего тела. Когда ртутный столбик поднимается выше $20{ }^{\circ} \mathrm{C}$ у коров снижаются потреб- ление корма по сухому веществу и продуктивность [5].

Заключение. Использование ОМЭК, $\mathrm{Cu}, \mathrm{Zn}$, $\mathrm{Mn}$, Со положительно влияет на молочную продуктивность и состав молока. Показатели морфологического и биохимического состава крови коров, получавших неорганические и органические формы микроэлементов, находились в пределах физиологических норм.

Результаты проведенного эксперимента дают основания для изучения премиксов с повышенным вводом в них неорганических и органических форм йода. Органические микроэлементные комплексы «ОМЭК-7М» производства АО «Биоамид» отличаются конкурентной способностью по сравнению с неорганическими солями микроэлементов.

\section{СПИСОК ЛИТЕРАТУРЫ}

1. Быкова Е.В., Коробов А.П., Гуменюк А.П. Влияние органического микроэлементного комплекса йода ОМЭК-Ј на метаболические процессы в организме дойных коров // Аграрный научный журнал. 2017. - № 6. - С. 3-6.

2. Влияние аспарагинатов микроэлементов на метаболизм молочных коров// А.П. Коробов [и др.]// Молочное и мясное скотоводство. - 2015. - № 4. C. 31-34.

3. Воронин С.П., Голубов И.И., Гуменюк А.П., Синолицкий. М.К. Биодоступная форма микроэлементных добавок в кормовые смеси для животных и птиц // Патент РФ № 2411747. 2008.

4. Использование гидропонного зеленого корма для оптимизации зимних рационов крупного рогатого скота //А.А. Васильев [и др.] // Аграрный научный журнал. - 2016. - № 3. -С. 13-16.

5. Калюжный И.И. Нарушение обмена веществ у молочных коров. Рекомендации. - Саратов, 2010. C. 20-23.

6. Нормы и рационы кормления сельскохозяйственных животных / под ред. А.П. Калашникова [и др.]. - 3-е изд., перераб. и доп. - М.: Россельхозакадемия, 2003. - 456 с.

7. Фисинин В.И. Инновационные пути развития свиноводства в России // Свиноводство. - 2010. № 1. - C. 4-7.

Содержание Лжк в содержимом рубца в конце опыта (в среднем по группам), \%

\begin{tabular}{|c|c|c|c|c|c|}
\hline \multirow{2}{*}{ Группа } & \multirow{2}{*}{$\begin{array}{c}\text { РН } \\
\text { содержимого }\end{array}$} & \multicolumn{4}{|c|}{ Летучие жирные кислоты } \\
\cline { 3 - 6 } & 6,94 & уксусная & пропионовая & масляная & сумма 3 кислот \\
\hline Контрольная & 6,92 & 72,71 & 15,41 & 11,88 & 100 \\
\hline 1-я опытная & 6,94 & 72,05 & 15,43 & 13,13 & 100 \\
\hline 2-я опытная & 65 & 16,55 & 11,40 & 100 \\
\hline \multicolumn{2}{|c|}{ Норма ЛЖК [3] } & 65 & 20 & 15 & \\
\hline
\end{tabular}

Таблица 5

Среднесуточный удой и состав молока

\begin{tabular}{|l|c|c|c|c|}
\hline \multirow{2}{*}{ Показатель } & Период & \multicolumn{3}{|c|}{ Группа } \\
\cline { 2 - 5 } & опыта & контрольная & 1 -я опытная & 2 -я опытная \\
\hline \multirow{2}{*}{ Среднесуточный удой, кг } & Предварительный & $21,42 \pm 0,76$ & $21,73 \pm 1,11$ & $21,44 \pm 1,42$ \\
\cline { 2 - 5 } & Учетный & $13,56 \pm 0,55$ & $14,37 \pm 1,16$ & $15,49 \pm 0,8^{*}$ \\
\hline Количество жира по группе, кг & Учетный & $51,81 \pm 2,36$ & $52,31 \pm 4,03$ & $56,56 \pm 2,83$ \\
\hline Количество белка по группе, кг & Учетный & $43,26 \pm 1,63$ & $44,82 \pm 3,53$ & $49,29 \pm 2,34^{*}$ \\
\hline
\end{tabular}

$$
* P>0,95 \text {. }
$$


Быкова Елена Владимировна, аспирант кафедры «Кормление, зоогигиена и аквакультура», Саратовский государственный аграрный университет имени Н.И. Вавилова. Россия.

Коробов Александр Петрович, $\partial-p$ c.- $x$. наук, проф. кафедры «Кормление, зоогигиена и аквакультура», Саратовский государственный аграрный университет имени Н.И. Вавилова. Россия.

Калюжный Иван Исаевич, $\partial-p$ вет. наук, проф. кафедры «Болезни животных и ветеринарно-санитарная экспертиза», Саратовский государственный аграрный универ- ситет имени Н.И. Вавилова. Россия.

410005, г. Саратов, ул. Соколовая, 335.

Тел.: (452) 69-24-25.

Гуменюк Анатолий Петрович, канд. хим. наук, сотрудник, АО «Биоамид». Россия.

410033, г. Саратов, ул. Международная, 27.

Тел.: (8452) 34-10-11.

Ключевые слова: органические и неорганические формы микроэлементов; органический комплекс йода; морфологический, биохимический состав крови коров; молочная продуктивность; жир; белок молока.

\title{
INFLUENCE OF THE ORGANIC AND NONORGANIC FORMS OF MICROELEMENTS ON METABOLIC PROCESSES IN THE ORGANISM OF MILK COWS
}

Bykova Elena Vladimirovna, Post-graduate Student of the chair "Feeding, Zoohy-giene and Aquaculture", Saratov State Agrarian University named after N.I. Vavilov. Russia.

Korobov Aleksander Petrovich, Doctor of Agricultural Sciences, Professor of the chair "Feeding, Zoohygiene and Aguaculture", Saratov State Agrarian University named after N.I. Vavilov. Russia.

Kalyuzhniy Ivan Isaevich, Doctor of Veterinary Sciences, Professor of the chair "Animal Diseases and Veterinarian-sanitarian Expertise", Saratov State Agrarian University named after N.I. Vavilov. Russia.

Gymenyuk Anatoliy Petrovich, Candidate of Chemical Sciences, Leading Re-searcher, AO «Bioamid». Russia.

Keywords: organic trace element complex of iodine; cows; milk productivity; fat; protein of milk; chemical composition; iodine content.

The article presents the experimental data on the comparative study of the influ-ence of inorganic and organic forms of trace elements on metabolic processes in the organism of milking cows. It has been established that various forms of trace elements affect the metabolic processes in the animals. The best indices, within the physiological norms, morphological and biochemical composition of the blood, were in animals that received organic compounds of manganese, zinc, copper, co-balt, selenium and iodine in the premix. The inclusion of organic forms of micro-elements in the rations of cows improves milk productivity and qualitative indica-tors of milk.

УдК 619:618:615.3:636.2

\section{ПРИМЕНЕНИЕ АНТИПЛАЦЕНТАРНОЙ КРОВИ И ПРЕПАРАТА «НИТАМИН» ДЛЯ ПРОФИЛАКТИКИ ЗАДЕРЖАНИЯ ПОСЛЕДА И СУБИНВОЛЮЦИИ МАТКИ КОРОВ}

\begin{abstract}
ДАРМЕНОВА Альбина Габдрахимовна, Казанская государственная академия ветеринарной медицины имени Н.Э. Баумана
\end{abstract}

ЮсуПОв Самат Равхатович, Казанская государственная академия ветеринарной медицины имени Н.Э. Баумана

ЗУХРАБОВ Мирзабек Гашимович, Казанская государственная академия ветеринарной медиизины имени Н.Э. Баумана

МАВЛИХАНОВ Ранис Фаридович, ООО АФ «Колос»

Приведены результаты исследований по применению антиплацентарной крови (АПК) и препарата «Нитамин» для профилактики задержания последа и субинволюиии матки коров. Показано, что применение АПК и препарата «Нитамин» улучшает общее состояние, ускоряет послеродовую инволюцию, снижает количество животных с задержанием последа и болезнями послеродового периода. Об этом свидетельствуют изменения в половъх органах, морфологические и биохимические показатели крови животных.

Введение. Молочное животноводство является основной отраслью агропромышленного комплекса, которая поддерживает стабильность на продуктовом рынке. Успехи в этом направлении зависят от уровня воспроизводства коров.

Распространение акушерско-гинекологических заболеваний - актуальная проблема промышленного животноводства, так как при этом нарушаются функции половых органов, что является причиной длительного бесплодия $[2,3,4]$. Акушерско-гинекологическая патология коров изучалась многими отечественными и зарубежными авторами, предложены разные средства и методы лечения и профилактики $[1,5,6]$, но их эффективность остается низкой.

С целью разработки эффективных методов профилактики задержания последа и послеродовых заболеваний коров нами были проведены исследования с применением антиплацентарной крови и препарата «Нитамин».

методика исследований. Исследования проводили на кафедре хирургии, акушерства и патологии мелких животных ФГБОУ ВО «Казанская государственная академия ветеринарной медицины имени Н.Э. Баумана» и на молочнотоварной ферме ООО АФ «Колос» Тетюшского района РТ. Объектом исследований служили ко- 